\title{
Evaluation of commercially available, wide-pore ultrafiltration membranes for production of $\alpha$-lactalbumin-enriched whey protein concentrate
}

\author{
C. Marella, ${ }^{*}$ K. Muthukumarappan, $\dagger$ and L. E. Metzger ${ }^{* 1}$ \\ *Midwest Dairy Foods Research Center, Department of Dairy Science, and \\ †Department of Agricultural and Biosystems Engineering, South Dakota State University, Brookings 57007
}

\begin{abstract}
Commercially available, wide-pore ultrafiltration membranes were evaluated for production of $\alpha$-lactalbumin ( $\alpha$-LA)-enriched whey protein concentrate (WPC). In this study microfiltration was used to produce a prepurified feed that was devoid of casein fines, lipid materials, and aggregated proteins. This prepurified feed was subsequently subjected to a wide-pore ultrafiltration process that produced an $\alpha$-LA-enriched fraction in the permeate. We evaluated the performance of 3 membrane types and a range of transmembrane pressures. We determined that the optimal process used a polyvinylidene fluoride membrane (molecular weight cut-off of $50 \mathrm{kDa}$ ) operated at transmembrane pressure (TMP) of $207 \mathrm{kPa}$. This membrane type and operating pressure resulted in $\alpha$-LA purity of $0.63, \alpha-\mathrm{LA}: \beta-\mathrm{LG}$ ratio of $1.41, \alpha$-LA yield of $21.27 \%$, and overall flux of $49.46 \mathrm{~L} / \mathrm{m}^{2} \cdot \mathrm{h}$. The manufacturing cost of the process for a hypothetical plant indicated that $\alpha$-LA-enriched WPC 80 (i.e., with $80 \%$ protein) could be produced at $\$ 17.92 / \mathrm{kg}$ when the price of whey was considered as an input cost. This price came down to $\$ 16.46 / \mathrm{kg}$ when the price of whey was not considered as an input cost. The results of this study indicate that production of a commercially viable $\alpha$-LA-enriched WPC is possible and the process developed can be used to meet worldwide demand for $\alpha$-LA-enriched whey protein.
\end{abstract}

Key words: membrane separation, $\alpha$-lactalbumin, whey protein concentrate, cheese whey

\section{INTRODUCTION}

The 2 major protein fractions in cheese whey are $\beta$-LG and $\alpha$-LA. Together, these fractions account for 70 to $80 \%$ of the total proteins in whey, but the concentration of $\beta-\mathrm{LG}$ is twice that of $\alpha-\mathrm{LA}$. The desire to use $\alpha-\mathrm{LA}$ in infant formula and other nutritional products has resulted in $\alpha$-LA being considered more valuable than

Received August 18, 2010.

Accepted November 20, 2010.

${ }^{1}$ Corresponding author: Lloyd.Metzger@sdstate.edu
$\beta$-LG. The use of $\alpha$-LA in health-related applications is based on numerous health benefits, including stress management and anticancer activity, that have been associated with $\alpha$-LA (Ganjam et al., 1997; Markus et al., 2000). Additionally, human $\alpha-\mathrm{LA}$ and oleic acid form a complex known as HAMLET (human $\alpha$-LA made lethal to tumor cells). This complex induces apoptosislike cell death in tumor cells (Svanborg et al., 2003) and acts as an antimicrobial agent against streptococcal pneumonia and hemophilus influenza (Chatterton et al., 2006). Similar findings have also been reported for bovine $\alpha$-LA (Chatterton et al., 2006; Yang et al., 2006). The worldwide demand for $\alpha$-LA is estimated to be $400 \mathrm{t} / \mathrm{yr}$ (Muller et al., 2003a) and is expected to continue to grow.

Previous research on production of $\alpha-\mathrm{LA}$-enriched whey protein products has used thermal treatments (Bramaud et al., 1995, 1997; Uchida et al., 1996; Kiesner et al., 2000), physical and chemical treatments (Pearce, 1995; Gésan-Guiziou et al., 1999; Tomasula and Parris, 1999), ion exchange chromatography (Heeboll-Nielsen et al., 2004; Turhan and Etzel, 2004; Ayers et al., 2006), and membrane separation using organic membranes in a hollow fiber configuration (Roger et al., 1984; Bottomley, 1991) and a combination of ceramic and organic membranes (Lucas et al., 1998; Muller et al., 2003a,b; Mehra and Kelley, 2004). Thermal, physical, and chemical treatments are primarily batch processes, have limited scale-up capabilities, and cause irreversible denaturation to the $\alpha$-LA fraction. The ion exchange process produces a highly enriched $\alpha$-LA product, but the process is expensive (Chatterton et al., 2006) and uses large quantities of chemicals. When compared with these processes, membrane separation processes are more cost effective and can be used on a large scale in a continuous process. Membrane separation is based on selective permeability of a porous membrane and separates the components based on differences in molecular size and shape. $\alpha$-Lactalbumin and $\beta$-LG differ in their molecular weight and isoelectric $\mathrm{pH}$. The molecular weight of $\alpha-\mathrm{LA}$ is $14 \mathrm{kDa}$ whereas that of $\beta-\mathrm{LG}$ (as dimer) is $36.8 \mathrm{kDa}$; their isoelectric $\mathrm{pH}$ are 4.2 to 4.5 and 5.2, respectively (Morr and Ha, 1993). These 
differences can be utilized in membrane fractionation of these proteins in cheese whey. In the United States, most whey processing applications use polymeric membranes. Consequently, any process developed using polymeric membranes could be easily adopted by whey processors and would facilitate production of an additional value added product using their existing facilities and equipment.

In membrane-based separation processes, the type of membrane and its molecular weight cut-off (MWCO), transmembrane pressure (TMP), temperature of operation, feed $\mathrm{pH}$, and so on are important operating variables that influence process efficiency. Microfiltration (MF) and UF processes are widely used in cheese whey processing. Although polyvinylidene fluoride (PVDF) membranes with porosity ranging from 0.1 to $0.5 \mu \mathrm{m}$ are widely used in MF, polyethersulfone (PES) membranes with porosity of 5 and $10 \mathrm{kDa}$ are widely used in conventional UF. These 2 membrane types differ in surface hydrophobicity and other chemical characteristics. The types of UF membranes and operating conditions used in selective fractionation of whey proteins are different from those used in the conventional UF process used to produce whey protein concentrate (WPC). In conventional UF, the main aim of the process is to concentrate all the protein fractions present in the whey. This process typically uses a TMP of $275 \mathrm{kPa}$ and uses tighter PES membranes. In the UF process used for selective fractionation of whey proteins, wide-pore membranes and lower TMP are required. Theoretically, a combination of MF (to remove residual fat, lipoproteins, and protein aggregates) and wide-pore UF (to selectively fractionate the $\alpha$-LA fraction and concentrate the $\alpha$-LA fraction streams) could be used as a viable processing technology for production of $\alpha-L A-$ enriched WPC. Thus, the purpose of this research was to evaluate commercially available wide-pore UF membranes for production of $\alpha$-LA-enriched WPC from MF Cheddar cheese whey. A total of 3 UF membranes and 3 TMP were evaluated. The specific objectives of the study were to select a suitable membrane type and optimum TMP based on overall flux, purity, and yield of $\alpha-\mathrm{LA}$ and $\alpha-\mathrm{LA}: \beta-\mathrm{LG}$ ratio in the product and to conduct a cost analysis of the developed process.

\section{MATERIALS AND METHODS}

\section{Experimental Design and Statistical Analysis}

Fresh Cheddar cheese whey was collected from the South Dakota State University dairy plant (Brookings). The whey was subjected to mechanical clarification and pasteurized at $63^{\circ} \mathrm{C}$ for $30 \mathrm{~min}$. The clarified and pasteurized whey was subjected to MF using a pilotscale filtration unit (MSS Inc., Wisconsin Rapids, WI) equipped with a $0.2-\mu \mathrm{m}$ spiral-wound PVDF membrane (Synder Filtration, Vacaville, CA) with a filtration area of $5.2 \mathrm{~m}^{2}$. Microfiltration was conducted at an applied TMP of $55 \mathrm{kPa}$, feed $\mathrm{pH}$ of 6.3 , process temperature of $31^{\circ} \mathrm{C}$, and volume reduction ratio (VRR) of 5 . The permeate from the MF process was used as the feed for the wide-pore UF studies for production of $\alpha$-LA-enriched WPC. Wide-pore UF experiments were conducted using a $3 \times 3$ factorial design. Three membrane types (PVDF50, PVDF100, and PES300) and 3 TMP $(110,207$, and $310 \mathrm{kPa})$ were used in the study. The PVDF50 (Synder Filtration) and PVDF100 (Parkar Hannifin Corp., Oxnard, CA) membranes are PVDF membranes with nominal MWCO of 50 and $100 \mathrm{kDa}$, respectively. The PES300 (Synder Filtration) membrane is a PES membrane with a nominal MWCO of $300 \mathrm{kDa}$. Selection of these membranes was based on preliminary research in which we screened PES membranes of 50,100, and $300 \mathrm{kDa}$ porosity and PVDF membranes with 50 and $100 \mathrm{kDa}$ porosity. A PVDF membrane with $300 \mathrm{kDa}$ porosity was not available. The 50 and $100 \mathrm{kDa}$ membranes were obtained from 2 different manufacturers because no single manufacturer produced both sizes. In the preliminary study, the PES membranes with 50 and $100 \mathrm{kDa}$ porosity did not give satisfactory fractionation results (the yield of $\alpha$-LA was of the order of 2-5\%). Consequently, the PES 50 and $100 \mathrm{kDa}$ membranes were not used in the study.

Each treatment combination was replicated 3 times giving 27 experimental runs. Statistical analysis on the collected data was done using the Proc GLM analysis of SAS (SAS Institute Inc., Cary, NC) with a Type I error rate $(\alpha)$ of 0.05 to test for significant differences among the treatments. Samples of feed, permeate, and retentate, as well as individual protein fractions, were analyzed for their composition.

\section{Wide-Pore UF}

Wide-pore UF experiments were conducted using a laboratory-scale plate and frame unit (Optisep 400 unit, part no. 20-000-1000) from SmartFlow Technologies (Apex, NC). The unit used flat sheet membranes of 14 $\times 15.2 \mathrm{~cm}$ with a filtration area of $0.02 \mathrm{~m}^{2}$. The gasket provided a channel height of $0.5 \mathrm{~mm}$ for the feed channel. The TMP was measured using a Duralife pressure gauge (Ashcroft Industrial, Stratford, CT; measuring range of 0 to $400 \mathrm{kPa}$ ) fitted to the end plate. The pressure was varied by controlling the back pressure valve provided on the retentate line at the outlet of the unit. A variable-speed peristaltic pump (Masterflex, cat. no. EW-77521-40, Cole Parmer, Vernon Hills, IL) coupled 


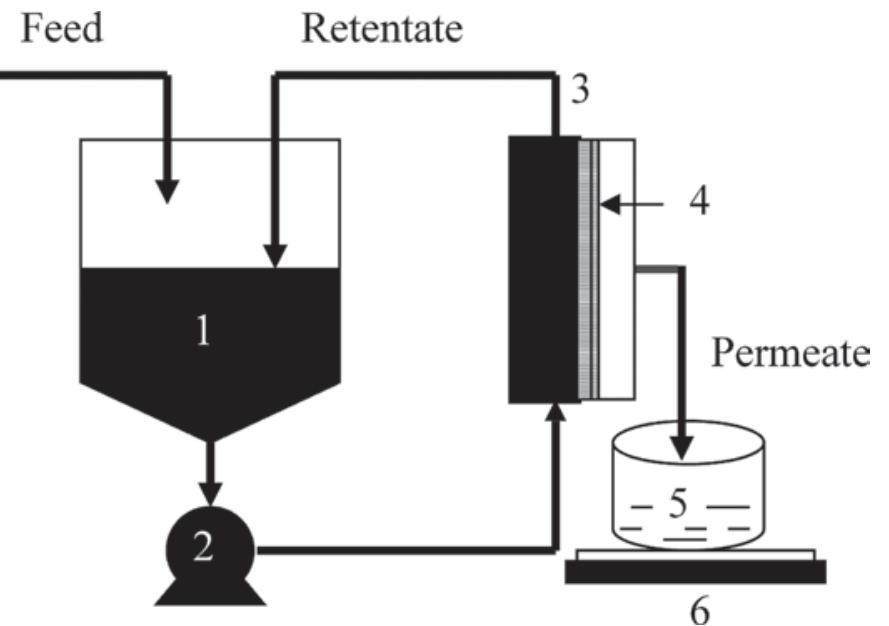

Figure 1. Schematic of membrane separation process: $1=$ feed tank, $2=$ pump, $3=$ filtration unit, $4=$ membrane, $5=$ permeate collection tank, 6 = weighing balance.

to a standard L/S pump head (cat. no. C-07024-21, Cole-Parmer) was used to supply the feed to the membrane unit. Feed flow rate to the membrane unit was maintained at $1.7 \mathrm{~L} / \mathrm{min}$. Flat sheet membranes were cut into pieces of $14 \times 15.2 \mathrm{~cm}$ and were assembled in the filtration unit according to the instruction manual supplied with the filtration unit. Before each run, the membrane was flushed with $4 \mathrm{~L}$ of deionized water and then conditioned by running $1 \mathrm{~L}$ of deionized water at a $\mathrm{pH}$ of 6.3 . Each batch was started with a feed volume of $1,350 \mathrm{~mL}$, and separation was done in continuous concentration mode as shown in Figure 1, to a final retentate volume of $270 \mathrm{~mL}$, thereby giving a VRR of 5. All the experiments were conducted at $31^{\circ} \mathrm{C}$ and $\mathrm{pH}$ of 6.3 .

\section{Proximate Analysis}

Samples of feed, permeate, and retentate were analyzed for TS, fat, protein $(\mathrm{N} \times 6.38)$ and ash using direct forced-air oven drying (AOAC, 2005; method 990.20), modified Mojonnier ether extraction (AOAC, 2005; method 989.05), Kjeldahl (AOAC, 2005; method 991.20), and gravimetric (AOAC, 2005; method 945.46) methods, respectively. Lactose content was determined by subtracting fat, protein, and ash contents from the TS content.

\section{Overall Flux}

Overall flux was calculated as permeate flow rate per unit filtration area per unit time and is expressed as liters per meter square per hour (LMH): $\frac{\text { permeate flow, } \mathrm{mL} \times 60}{\text { collection time, } \min \times \text { area of membrane } \times 1,000}$.

In the present study, overall flux was averaged over the entire process time. The feed volume and volume reduction used in the study resulted in a process time of about $60 \mathrm{~min}$. In preliminary research, extended filtration runs in excess of $4 \mathrm{~h}$ were tested. In this preliminary testing, using MF whey the decrease in overall flux during the first 30 to $45 \mathrm{~min}$ was $24 \%$. Over the next $3 \mathrm{~h}$, the flux remained relatively constant and decreased by only $9 \%$. Consequently, the overall flux determined during $60 \mathrm{~min}$ of processing in the study provides a reasonable assessment of membrane performance. Other researchers have reported that the use of MF whey reduces fouling of UF membranes (Lee and Merson, 1976).

\section{Determination of Purity, Yield, and Transmission of $\alpha-L A$}

The purity of $\alpha$-LA was determined as the ratio of its peak area to the total area of all the peaks in the chromatogram obtained by reverse-phase HPLC (Alomirah and Alli, 2004). The HPLC was performed on a $\mathrm{C} 4$ reverse phase column $(0.46 \times 25 \mathrm{~cm}$ length Jupiter column, Phenomenex, Torrance, CA) using an Agilent 1200 series LC unit equipped with a UV visible multiwavelength detector (Agilent Technologies, New Castle, DE). A binary gradient consisting of solvent A $[0.065 \%$ ( vol/vol) trifluoroacetic acid in deionized water $(\mathrm{pH}$ $=2.2)]$ and solvent $\mathrm{B}[10: 90$ ratio of $0.055 \%$ ( $\mathrm{vol} / \mathrm{vol})$ trifluoroacetic acid in deionized water and acetonitrile] was used for eluting the protein fractions (Casal et al., 2006). The absorbance was measured at $214 \mathrm{~nm}$. Quantification of individual protein fractions was done based on the areas of the peaks of the protein fractions. The peak areas were transformed into concentrations based on the standard curves obtained by injecting known concentrations of the protein standards. The protein standards were purchased from Sigma Chemical (St. Louis, MO) and included $\alpha$-LA (cat. no. L6010), $\beta$-LG A (cat. no. L7880), and $\beta$-LG B (cat. no. L8005). Stock solutions of individual protein standards were prepared in Milli-Q water (Milli Q water system, Thermo Scientific, Asheville, NC) and were stored at $-20^{\circ} \mathrm{C}$. Six-point standard curves were constructed for each protein fraction from the mixed standards using injection volumes from 20 to $100 \mu \mathrm{L}$. The yield of $\alpha$-LA was calculated as the total quantity of $\alpha$-LA recovered in the permeate expressed as percentage of that present in the feed: 


$$
\text { Yield }=\frac{\mathrm{Cp} \times \mathrm{V}}{\mathrm{Cf} \times \mathrm{V}},
$$

where $\mathrm{C}$ and $\mathrm{V}$ are the concentration of protein fraction and volume and $\mathrm{f}$ and $\mathrm{p}$ are feed and permeate, respectively. In quantification of $\alpha$-LA, a shoulder peak appearing just before $\alpha$-LA peak and measuring about 15 to $20 \%$ of the major peak was considered as part of $\alpha$-LA peak. From electrospray ionization-mass spectroscopy, Couriol et al. (2000) identified this peak as $\alpha$-LA linked to one lactose molecule. Accordingly, in the present study, this shoulder was considered part of $\alpha$-LA. Transmission (Tr) of $\alpha-\mathrm{LA}$ was expressed as the ratio of concentration $(\mathrm{C})$ of $\alpha-\mathrm{LA}$ in the permeate $(\mathrm{p})$ and retentate $(\mathrm{r})$ :

$$
\alpha-\mathrm{LA} \operatorname{Tr}=\frac{\mathrm{Cp}}{\mathrm{Cr}}
$$

\section{Electrophoresis}

Sodium dodecyl sulfate-PAGE was conducted using a PhastSystem (Pharmacia LKB, Uppsala, Sweden). The cheese whey samples were diluted with a $\mathrm{pH}$ 6.8 buffer containing $0.12 \%$ Trizma base, $0.02 \%$ bromophenol blue (tracking dye), and 1\% SDS. A 0.1-mL sample of whey was mixed with $0.9 \mathrm{~mL}$ of the above buffer containing $\beta$-mercaptoethanol (20:1 ratio). The samples were heated in a boiling water bath for $5 \mathrm{~min}$. Subsequently, $10 \mu \mathrm{L}$ of the sample was applied to the wells and the separation program was run for $300 \mathrm{~V} \cdot \mathrm{h}$ (approximately 20-25 min). Staining was done with PhastGel Blue R (0.1\% concentration in methanol, acetic acid, and deionized water in approximately 3:1:6 ratio; Pharmacia LKB). Destaining was done with a solution of methanol, acetic acid, and deionized water in 3:1:6 proportion. Development of the gel was done according to the development technique file 200 (Pharmacia LKB). All the chemicals except SDS were from Sigma Aldrich (St. Louis, MO); SDS was from Life Technologies (Gaithersburg, MD).

\section{Cost Analysis}

The cost analysis of the membrane separation process was conducted for a hypothetical WPC plant that handles $392,727.3 \mathrm{~kg}$ of whey per day (e.g., a cheese plant handling 960,000 lbs of milk per day yielding $864,000 \mathrm{lbs}$ of whey), operating $21 \mathrm{~h} / \mathrm{d}, 6 \mathrm{~d} / \mathrm{wk}$. It was assumed that whey at $31^{\circ} \mathrm{C}$ was received from the cheese making facility after it was run through a fines saver and a centrifugal clarifier. The whey was pasteur- ized at $72^{\circ} \mathrm{C}$ for $15 \mathrm{~s}$ and immediately cooled to $31^{\circ} \mathrm{C}$ before being taken to the MF plant (Figure 2). All the membrane units were spiral-wound type with standard 3838 elements of PVDF and PES membranes. The retentates from UF plant II (UF II in Figure 2) and UF plant III (UF III in Figure 3)were directly spray-dried to a final moisture content of $4 \%$. The individual costs were taken from Hurst et al. (1990), Papadatos et al. (2003), and Peters (2005) with an inflation of $3 \%$ per annum. The price of whey was based on the prevailing price of whey in the Wisconsin region. Break-even was assumed on the permeate handling. Retentates from MF and UF plant I (UF I in Figure 1) were combined and processed into WPC 80 (WPC with $80 \%$ protein; Figure 3$)$. Microfiltration operated at $76 \mathrm{kPa}$ TMP with overall flux of $120 \mathrm{LMH}$ and VRR of 5 . Ultrafiltration I operated at $207 \mathrm{kPa}$ TMP with overall flux of $50 \mathrm{LMH}$ and VRR of 5 . The permeate from this process was the $\alpha$-LA-enriched stream with a purity of 0.63 and $\alpha$-LA: $\beta-L G$ ratio of 1.41 . Ultrafiltration II operated at $207 \mathrm{kPa}$ TMP with overall flux of $20 \mathrm{LMH}$ and VRR of 250 . The actual yield of whey protein products was considered to be $90 \%$ of theoretical yield.

\section{RESULTS AND DISCUSSION}

\section{Overall Flux}

The mean squares for overall flux analyzed with SAS are presented in Table 1. Overall flux was significantly $(P<0.05)$ influenced by TMP and membrane type, whereas the interaction of TMP $\times$ membrane type was not significant $(P>0.05)$. From the data for treatment effects (Figure 4a) it is clear that the overall flux rates of 45.37, 44.75, and 53.12 LMH obtained at 310 $\mathrm{kPa}$ for PVDF50, PVDF100, and PES300 membranes, respectively, were the lowest flux rates for the respective membranes. The overall flux rates of $65.62,69.85$, and 102.74 LMH obtained for these membranes at the TMP of $110 \mathrm{kPa}$ were the highest for the respective membranes. The TMP of 110 and $310 \mathrm{kPa}$ were the lowest and highest pressures used in the present study, respectively. In membrane filtration of biological materials, fouling of the membrane surfaces with lipid material, proteins, and salts dictates the permeation and flux rates (Merin and Cheryan, 1980). The fouled layer behaves as a pseudo filtration layer and changes the characteristics of the actual membrane. Higher TMP cause increased fouling and resistance of the membrane (Attia et al., 1991) leading to lower flux rates (Bentham et al., 1988). Higher TMP also lead to formation of a compact and dense layer of fouling material on the surface of the membrane, thereby lowering the flux rates. On the other hand, lower TMP will lead to formation of 
a more open porous layer of the foulants on the surface of the membrane, which results in better flux rates. Of the 3 membranes studied, the highest overall flux of 102.74 LMH was obtained for PES300 operated at a TMP of $110 \mathrm{kPa}$. The overall fluxes obtained with the 2 PVDF membranes operated at TMP of $110 \mathrm{kPa}$ were not statistically different. The overall fluxes obtained with the PVDF50 membrane operated at 110 and 207 $\mathrm{kPa}$ were 65.62 and 49. 46 LMH, respectively, consider- ably higher than the overall flux reported for a $50 \mathrm{kDa}$ ceramic membrane operated at $100 \mathrm{kPa}$ (Muller et al., 2003a).

The loss of flux as a function of time for the PVDF50 membrane operated at various TMPs and for all the 3 membranes operated at $207 \mathrm{kPa}$ pressure is shown in Figure 5, panels a and b. From the data presented in Figure 5a it is clear that the PVDF50 membrane operated at a TMP of $110 \mathrm{kPa}$ gave higher flux rates at all

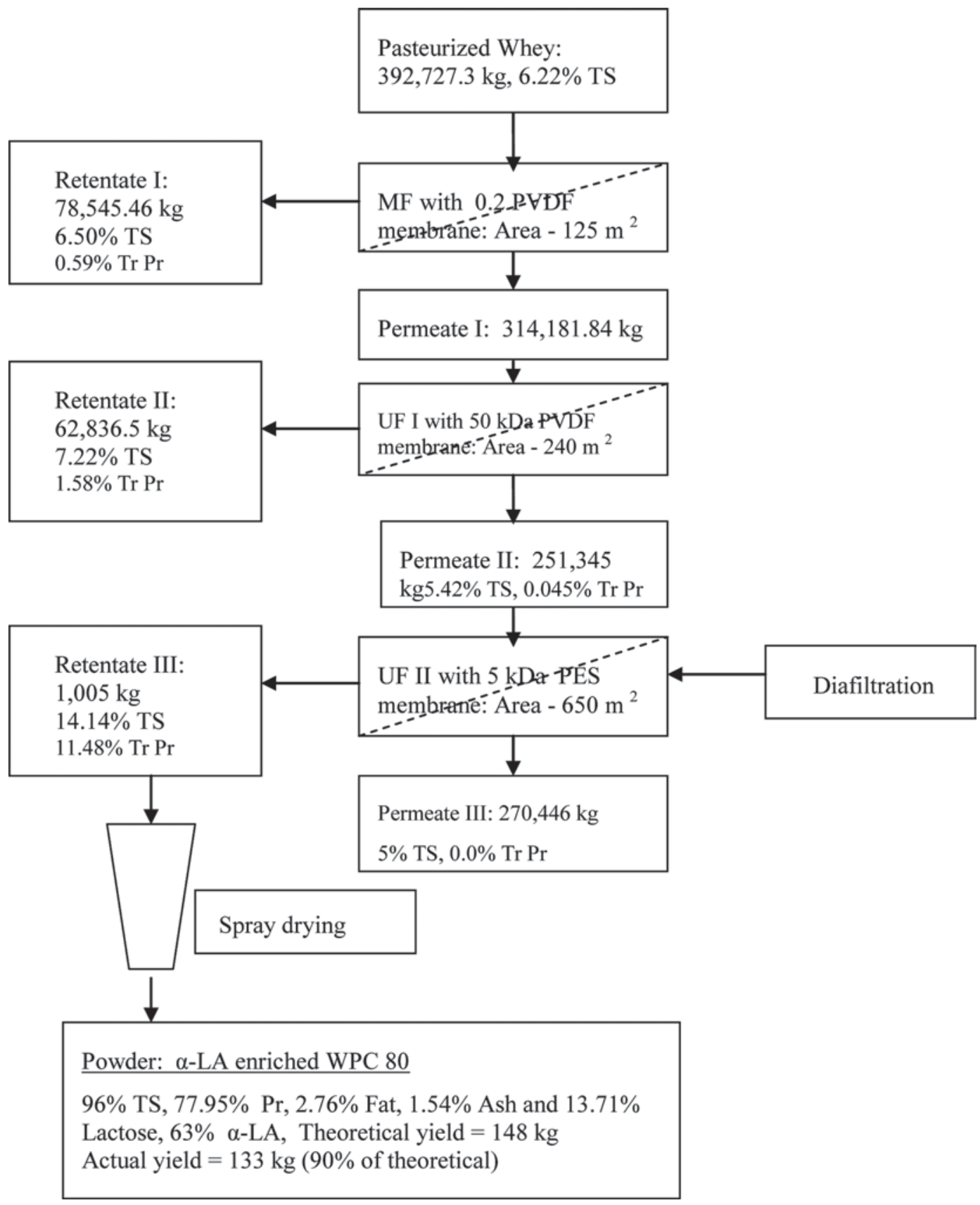

Figure 2. Process flow sheet along with material balance for $\alpha$-LA-enriched whey protein concentrate $(\mathrm{WPC}) 80$. Tr Pr $=$ true protein; $\mathrm{PVDF}=$ polyvinylidene fluoride $\mathrm{PES}=$ polyethersulfonel; $\mathrm{MF}=$ microfiltration. 
Table 1. Mean squares ( $P$-values in parentheses) for various parameters

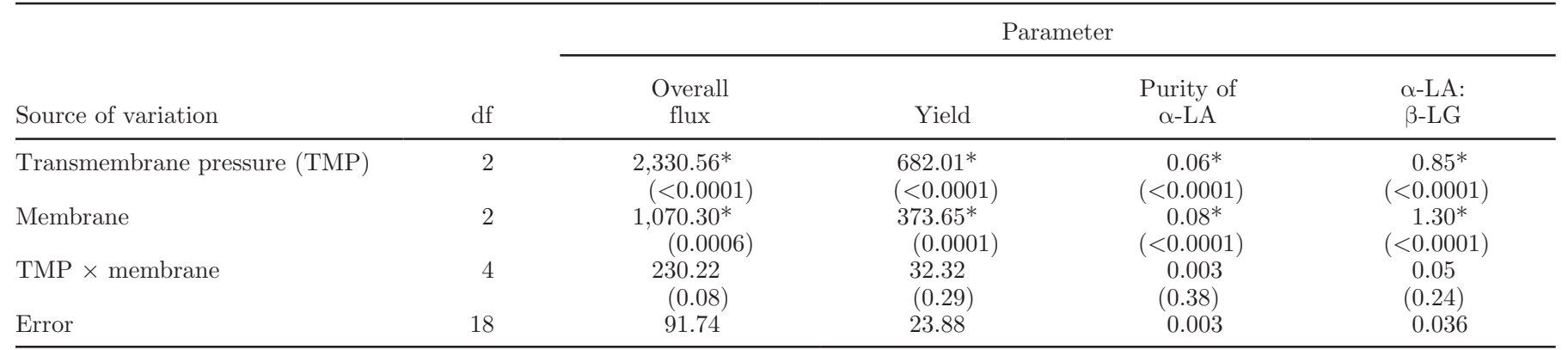

${ }^{*} P<0.05$.

time intervals. The flux rates at TMP of 207 and 310 $\mathrm{kPa}$ were similar for this membrane. From the slopes of the curves it can be seen that the rate of loss of flux at higher TMP was higher compared with loss of flux at lower TMP $(110 \mathrm{kPa})$ used in the study. As seen from the data presented in Figure 5b, even though the flux rates were quite different during the initial stages of the process, the difference in flux rates for PVDF50 and PVDF100 narrowed as the process proceeded and the overall flux rates were not significantly $(P>0.05)$ different (Figure 4a). Flux behavior at other TMP and with other membranes showed a similar trend (data not shown). Other researchers have reported similar changes in flux rates during processing. In UF of sweet whey using a $20 \mathrm{kDa}$ zirconium oxide membrane, the flux decreased considerably during the first 45 to $60 \mathrm{~min}$ and then remained relatively constant for the next $3 \mathrm{~h}$ of processing (Taddei et al., 1988). Kuo and Cheryan (1993) reported a similar trend in flux during UF of acid whey using spiral-wound polysulfone membranes.

\section{Yield of $\alpha-L A$}

The yield of $\alpha$-LA obtained (Table 1 ) in the permeate was significantly $(P<0.05)$ affected by TMP and the membrane type whereas the interaction of TMP $\times$ membrane type was not significant $(P>0.05)$. The yield data for treatment effects are presented in Figure 4b. It can be seen from the data that TMP of 110 $\mathrm{kPa}$ resulted in yields of $33.87,41.43$, and $47.64 \%$ for PVDF50, PVDF100, and PES300 membranes, respectively. These were the highest yields obtained among the 3 TMP studied. Among the 3 membranes studied, PES300 operated at 110, 207, and $310 \mathrm{kPa}$ TMP resulted in $\alpha$-LA yields of $47.64,35.84$, and $31 \%$, respectively; these values were the highest values obtained at the respective TMP. In a similar study using reconstituted acid type PWC powder as the feed, Muller et al. (2003a) reported an $\alpha$-LA yield of 16,31 , and $40 \%$ for 150,220 , and $300 \mathrm{kDa}$ ceramic membranes, respectively. The yield of $\alpha$-LA reported for a $50-\mathrm{kDa}$ ceramic membrane at a TMP of $100 \mathrm{kPa}$ was about $23 \%$ when prepurified feed was used (Muller et al., 2003b).

\section{Purity of $\alpha-L A$}

The purity of $\alpha$-LA in the permeate stream (Table 1) was significantly affected $(P<0.05)$ by the TMP and the membrane, whereas the interaction of TMP $\times$ membrane type was not significant $(P>0.05)$. The data on purity of $\alpha$-LA for treatment effects are pre-

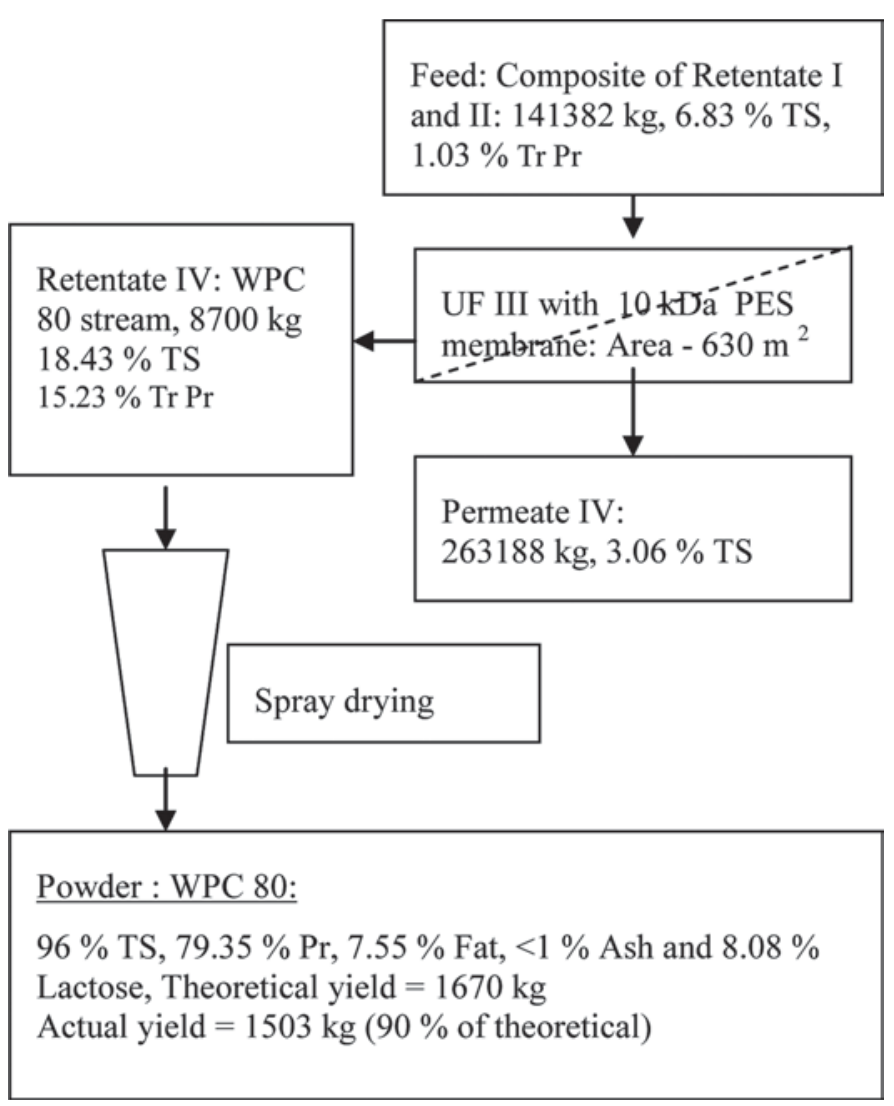

Figure 3. Process flow sheet along with material balance for conventional whey protein concentrate $(\mathrm{WPC}) 80 . \mathrm{Tr} \operatorname{Pr}=$ true protein; $\mathrm{Pr}=$ protein; $\mathrm{PES}=$ polyethersulfone. 
a)

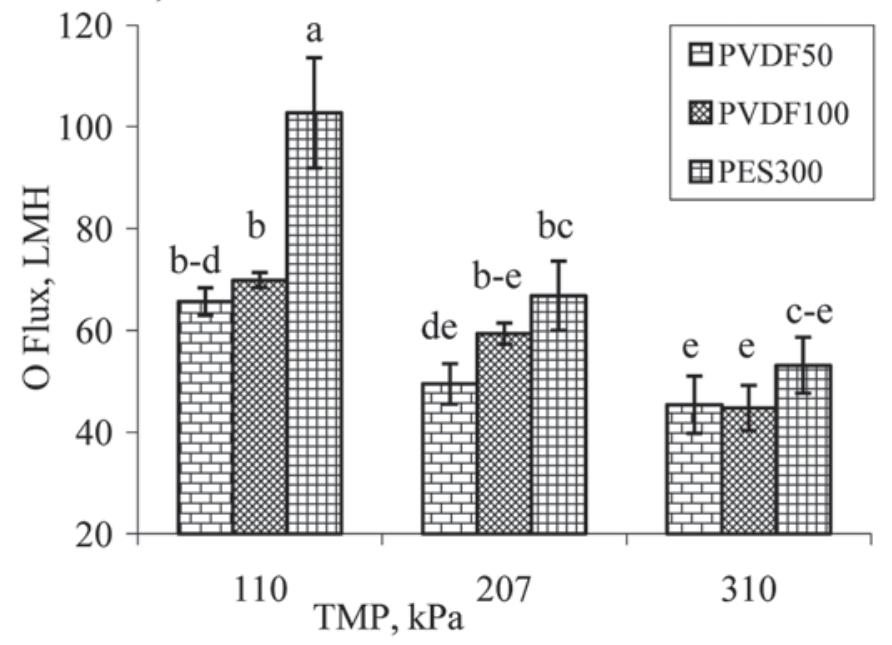

c)

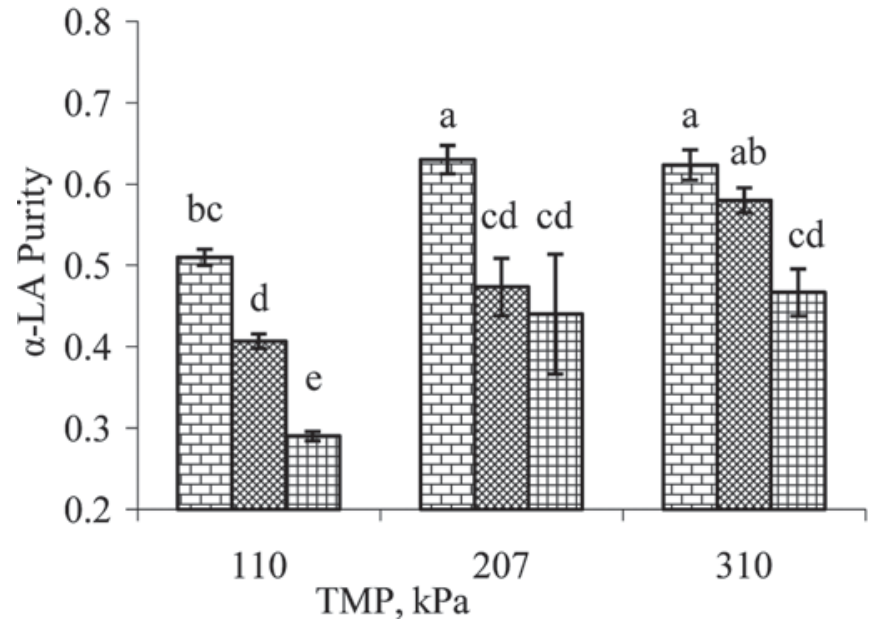

b)

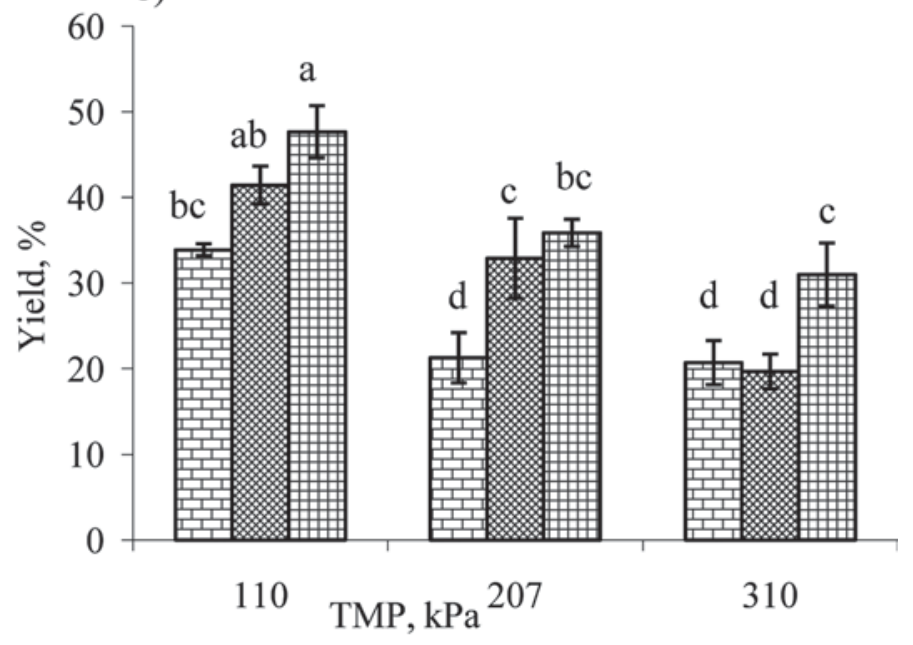

d)

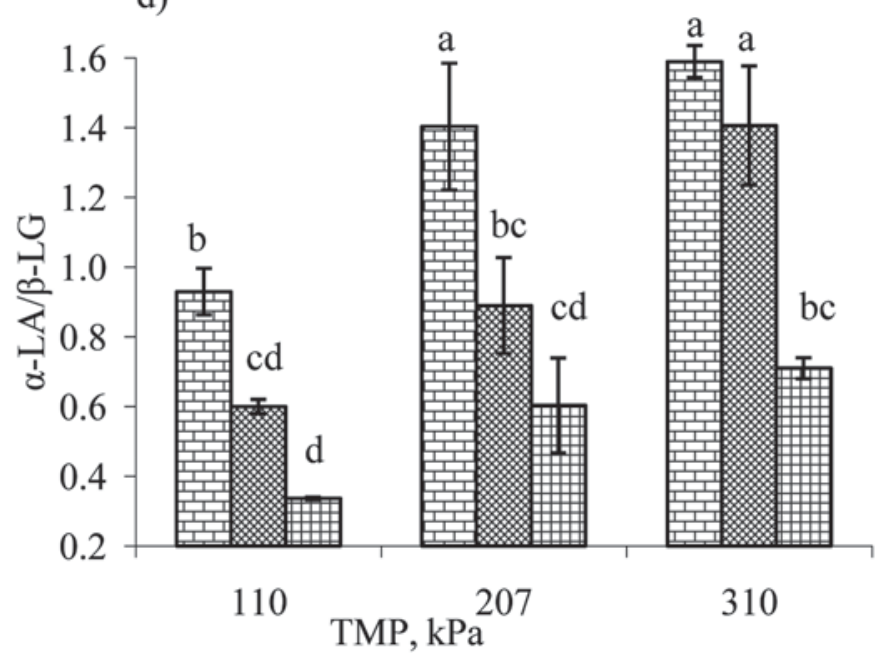

Figure 4. a) Overall flux (O Flux; L/m².h, LMH); b) $\alpha$-LA yield; c) $\alpha$-LA purity; d) $\alpha$-LA: $\beta$-LG ratio at different transmembrane pressures (TMP); PVDF50 and PVDF100 are polyvinylidene fluoride membranes with 50 and 100 kDa molecular weight cut-offs, and PES300 is a polyethersulfone membrane with $300 \mathrm{kDa}$ molecular weight cut-off. Experimental conditions: volume reduction ratio $=5$, temperature $=31^{\circ} \mathrm{C}$, and $\mathrm{pH}=6.3$.

sented in Figure 4c. Initial purity of $\alpha$-LA in the feed was 0.28 . The highest purity obtained in the experiments was 0.63 for the PVDF50 membrane operated at $207 \mathrm{kPa}$ TMP. This purity level was not significantly different from that obtained at $310 \mathrm{kPa}$ pressure for PVDF 50 and PVDF100 membranes (Figure 4c). For a similar type of study Muller et al. (2003b) reported purity of 0.5 to 0.6 for a $50 \mathrm{kDa}$ ceramic membrane. The purity of $\alpha$-LA can only be improved by keeping $\beta$-LG transmission to the lowest possible value, which simultaneously decreases the transmission of $\alpha$-LA. Lower transmission of $\alpha$-LA means decreased yield of this fraction in the permeate. Protein transmission in the UF process is dictated by the combined effect of reduction in membrane pore size, electrostatic interac- tion of the fouled membrane, and the flux rates through the membrane. The higher the flux rates, the higher the protein transmission values and vice versa (Muller et al., 2003a). From the results presented in Figure 4c, the higher yields corresponded to higher $\alpha$-LA transmission (Table 2) and the lowest yield at $310 \mathrm{kPa}$ corresponds to the lowest $\alpha$-LA transmission value obtained (Table 2) at this TMP.

\section{Ratio of $\alpha-L A: \beta-L G$}

The ratio of $\alpha$-LA: $\beta-\mathrm{LG}$ is an indication of selective permeability of any membrane for $\alpha$-LA. The feed material used in the fractionation study had an $\alpha$-LA: $\beta$ LG ratio of 0.33 . The $\alpha-\mathrm{LA}: \beta-\mathrm{LG}$ ratio (Table 1 ) was 
a)

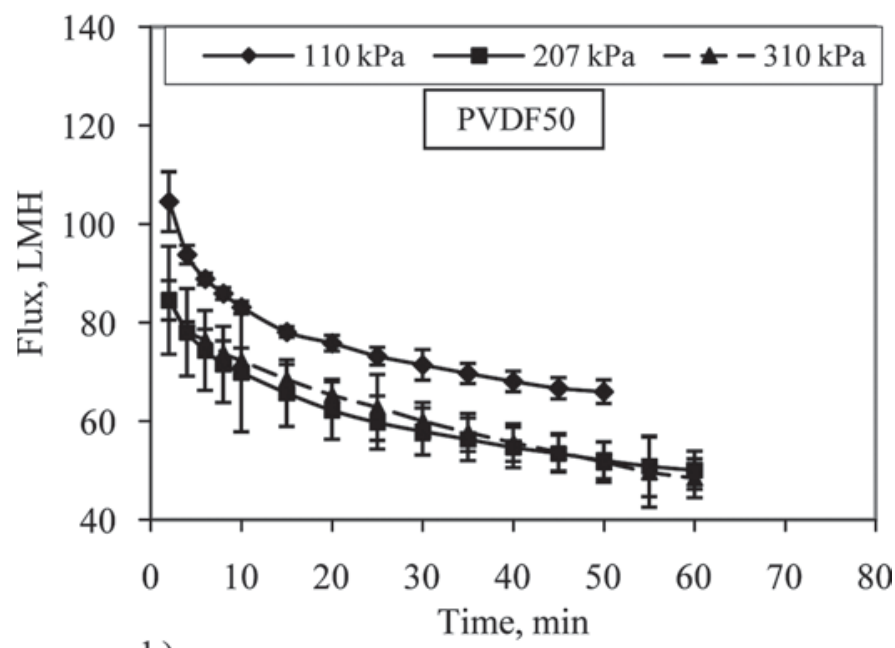

b)

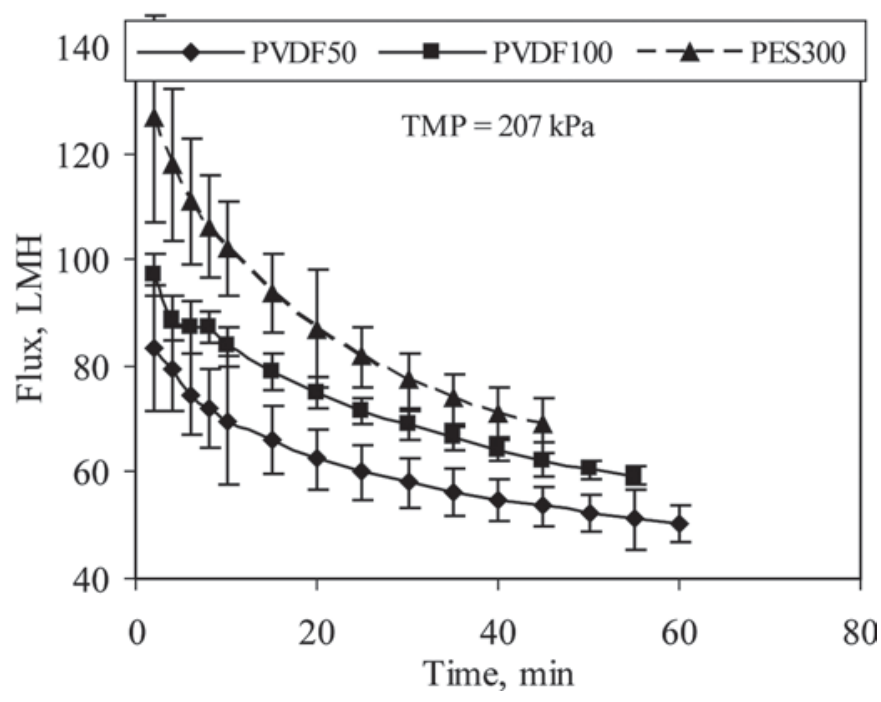

Figure 5. Flux through the membrane as a function of time for a) polyvinylidene fluoride $50 \mathrm{kDa}$ molecular weight cut-off membrane (PVDF50) operated at various transmembrane pressures (TMP); b) various membranes at a TMP of $207 \mathrm{kPa}$; PES300 is a polyethersulfone membrane with $300 \mathrm{kDa}$ molecular weight cut-off. PVDF100 is a polyvinylidene fluoride membrane with $100 \mathrm{kDa}$ molecular weight cutoff. Experimental conditions: volume reduction ratio $=5$, temperature $=31^{\circ} \mathrm{C}$, and $\mathrm{pH}=6.3 . \mathrm{LMH}=\mathrm{L} / \mathrm{m}^{2} \cdot \mathrm{h}$.

significantly affected $(P<0.05)$ by the TMP and the membrane type, whereas the interaction of TMP $\times$ membrane type was not significant $(P>0.05)$. The data on $\alpha$-LA: $\beta$-LG ratios for treatment effects are shown in Figure $4 d$. The $\alpha-L A: \beta-L G$ ratios obtained in the permeate with PVDF50 membrane operated at 207 and $310 \mathrm{kPa}$ pressures were 1.41 and 1.59 , respectively, and these values were not significantly different $(P>$ $0.05)$ from each other. Transmembrane pressure of 110 $\mathrm{kPa}$ resulted in to the lowest $\alpha-\mathrm{LA}: \beta-\mathrm{LG}$ ratio. At this TMP, the highest overall flux and yield were obtained.
In a similar study, Mehra and Kelley (2004) reported $\alpha$-LA: $\beta$-LG ratios of 0.9 and 0.55 for 50 and $100 \mathrm{kDa}$ hollow fiber membranes.

\section{Selection of Membrane Type and TMP}

In production of $\alpha-\mathrm{LA}$-enriched WPC, overall flux, yield of $\alpha$-LA, purity, and $\alpha-\mathrm{LA}: \beta-\mathrm{LG}$ ratio are all important parameters. For an ideal process, all these parameters should be high. From the results presented in the preceding sections it is clear that higher overall flux and yields corresponded to lower purity and lower $\alpha$-LA: $\beta$-LG ratio. Both the membrane type and operating pressure influence these parameters. Our results show that higher TMP resulted in lower yields and vice versa (Figure $4 \mathrm{~b}$ ) and that lower $\alpha$-LA purity and lower $\alpha$-LA: $\beta$-LG ratio were obtained at lower TMP. For WPC to be called $\alpha$-LA-enriched WPC, the $\alpha$-LA content in the product should be equal to or greater than $50 \%$ (purity of 0.5 or higher). As seen from the data presented in Figure 4c, of the various combinations of TMP and membrane type, PVDF50 at all the TMP and PVDF100 at a TMP of $310 \mathrm{kPa}$ resulted in $\alpha-\mathrm{LA}$ purity of $>0.5$. When it comes to relative concentrations of $\alpha$-LA and $\beta$-LG ( $\alpha$-LA: $\beta-L G$ ratio in Figure $4 \mathrm{~d}$ ), PVDF50 membrane at a TMP of 207 and $310 \mathrm{kPa}$ and PVDF100 membrane at $310 \mathrm{kPa}$ resulted in an $\alpha$-LA: $\beta$ $\mathrm{LG}$ ratio of $>1$. Based on the purity and $\alpha-\mathrm{LA}: \beta-\mathrm{LG}$ ratio data, the PVDF50 membrane at TMP of 207 and $310 \mathrm{kPa}$ and PVDF100 membrane at TMP of $310 \mathrm{kPa}$ appear to be the best combinations for obtaining a product with purity of $>0.5$ and an $\alpha-\mathrm{LA}: \beta-\mathrm{LG}$ ratio of $>1$. As the purity and $\alpha-L A: \beta-L G$ ratios for these combinations were not statistically different and because it is always beneficial to operate the process at lower

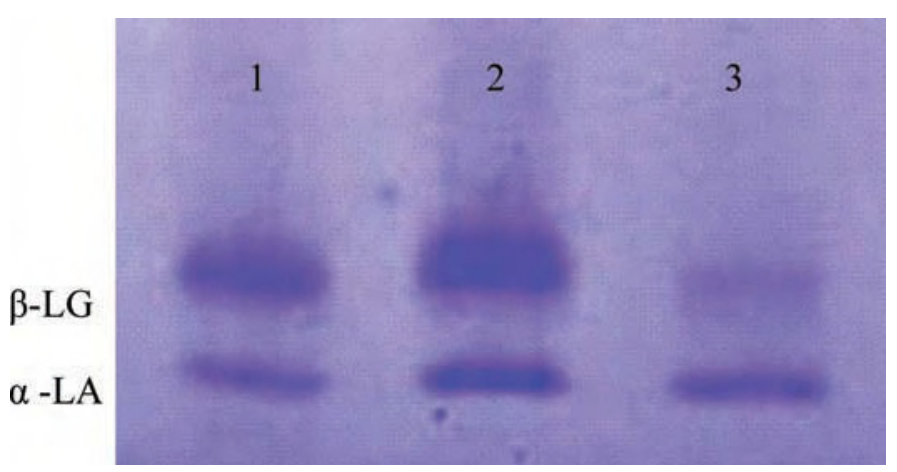

Figure 6. Sodium dodecyl sulfate-PAGE with PhastGel gradient 8-25 (Phamacia LKB, Uppsala, Sweden) showing $\alpha$-LA and $\beta$-LG from protein standards, feed, and permeate. Lane $1=$ protein standards; lane 2 = feed sample; lane $3=$ permeate sample at volume reduction ratio of 5 obtained with $50 \mathrm{kDa}$ polyvinylidene fluoride membrane operated at a transmembrane pressure of $207 \mathrm{kPa}$ and $\mathrm{pH}$ of 6.3 . Color version available in the online PDF. 
Table 2. Transmission values (SE in parentheses) of $\alpha-\mathrm{LA}^{1}$

\begin{tabular}{lccc}
\hline & \multicolumn{3}{c}{ Transmembrane pressure, $\mathrm{kPa}$} \\
\cline { 2 - 4 } Membrane $^{2}$ & 110 & 207 & 310 \\
\hline PVDF50 & $0.22^{\text {bc }}$ & $0.12^{\text {cde }}$ & $0.11^{\text {de }}$ \\
& $(0.00)$ & $(0.02)$ & $(0.03)$ \\
PVDF100 & $0.3^{\mathrm{b}}$ & $0.19^{\text {cde }}$ & $0.1^{\mathrm{e}}$ \\
& $(0.03)$ & $(0.03)$ & $(0.02)$ \\
PES300 & $0.43^{\mathrm{a}}$ & $0.21^{\mathrm{bcd}}$ & $0.18^{\mathrm{cde}}$ \\
& $(0.07)$ & $(0.04)$ & $(0.03)$ \\
\hline
\end{tabular}

${ }^{\mathrm{a}-\mathrm{e}}$ Means not followed by the same letter are significantly different $(P$ $<0.05)$

${ }^{1}$ Average of 3 replicates.

${ }^{2}$ PVDF50 and PVDF100 are polyvinylidene fluoride membranes with molecular weight cut-offs of 50 and $100 \mathrm{kDa}$, respectively; PES300 is a polyethersulfone membrane with a molecular weight cut-off of 300 $\mathrm{kDa}$.

TMP (in terms of energy consumption), we recommend use of a PVDF50 membrane and TMP of $207 \mathrm{kPa}$ for production of $\alpha$-LA-enriched WPC. From the chromatographic analysis, the $\alpha$-LA stream obtained with the above membrane and TMP combination had $63 \%$ purity. To verify the chromatographic data, SDS-PAGE was run on $\alpha$-LA stream from optimal combinations of membrane and TMP. The $\alpha$-LA stream obtained from the recommended combination showed (Figure 6) a higher concentration $\alpha$-LA relative to $\beta$-LG, confirming the HPLC results.

\section{Cost Analysis}

Commercial adoption of the developed manufacturing process will be dependent on the cost of manufacturing. The developed process for production of $\alpha$-LA-enriched WPC using the PVDF50 membrane operated at a TMP of $207 \mathrm{kPa}$ for $\alpha$-LA purification is shown in Figure 7. The process flow and the material balances for $\alpha$-LA-enriched WPC and conventional WPC 80 obtained as co-products from the developed process are shown in Figures 2 and 3. The manufacturing costs for a WPC plant handling $392,727.3 \mathrm{~kg}$ of whey per day (cheese plant handling 960,000 lbs of milk per day giving 864,000 lbs of whey) are shown in Table 3. In the cost analysis of the process, different components of the costs reported by Hurst et al. (1990) for a WPC 34 plant were inflated at $3 \%$ per annum. Additionally, an MF plant was included in the cost analysis to produce the purified feed for $\alpha$-LA purification. From the data presented in Table 3, it can be seen that the manufacturing cost of $\alpha$-LA-enriched WPC 80 was calculated to be $\$ 17.92 / \mathrm{kg}$ when the price of liquid whey was considered as an input cost. The cost excluding whey was $\$ 16.46$. The results of this study indicate that production of a commercially viable $\alpha$-LA-enriched WPC is possible and the developed process can be used to meet the world demand for $\alpha$-LA-enriched whey protein.

\section{CONCLUSIONS}

Experiments were conducted to evaluate commercially available, wide-pore UF membranes for production of $\alpha$-LA-enriched WPC. Of the 3 types of membranes and 3 TMP studied, a PVDF50 membrane operated at 207 $\mathrm{kPa}$ resulted in an $\alpha-\mathrm{LA}$-enriched product stream with a purity of 0.63 and $\alpha-\mathrm{LA}: \beta-\mathrm{LG}$ ratio of 1.41 . Based on the results, a 3-step process can be adopted for production of $\alpha$-LA-enriched WPC 80. The first step involves MF of clarified and pasteurized whey using a $0.2-\mu \mathrm{m}$ PVDF membrane operated at a feed $\mathrm{pH}$ of 6.3 , transmembrane pressure of $76 \mathrm{kPa}$, and a VRR of 5 . Second, $\alpha-L A$ can be fractionated from the MF permeate using the PVDF50 membrane operated at $207 \mathrm{kPa}$ TMP, $\mathrm{pH}$ of 6.3 , and to a VRR of 5. Finally, concentration of
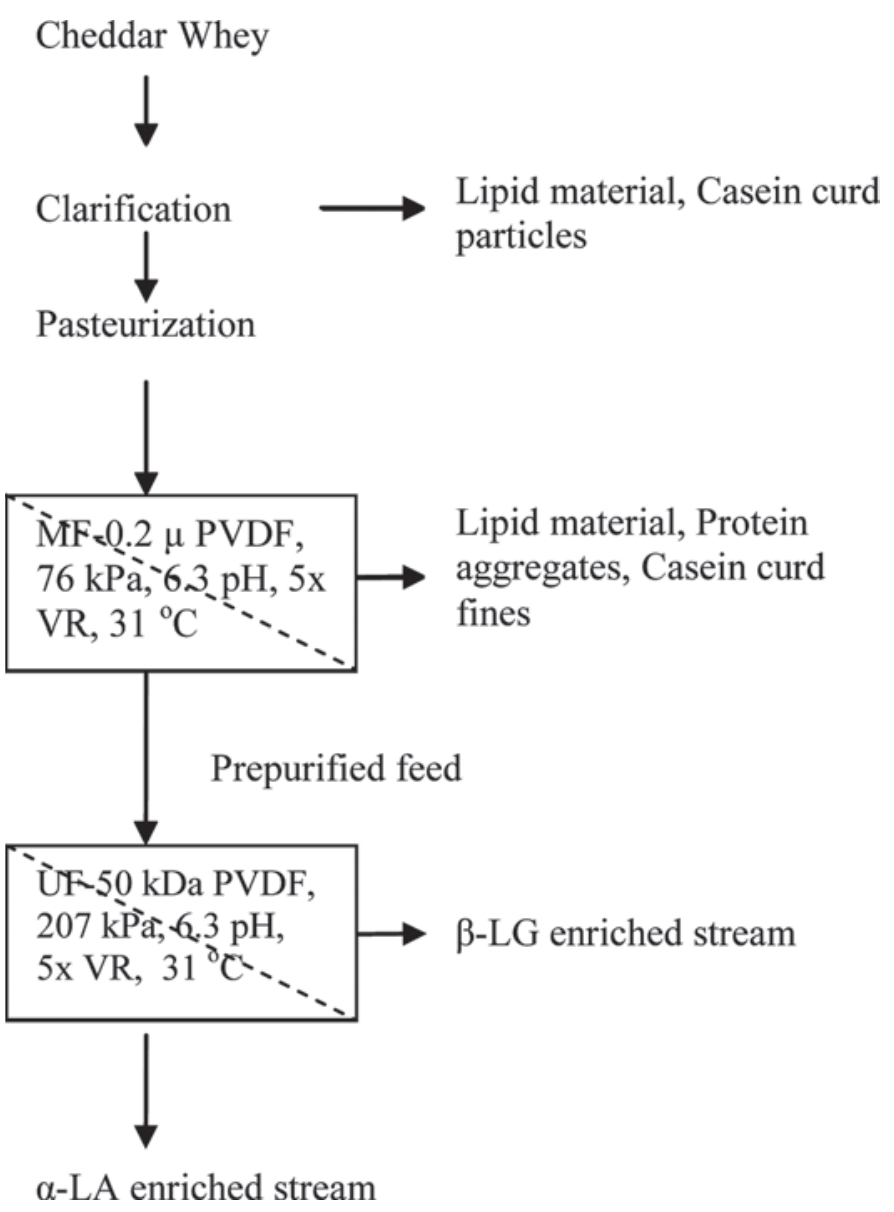

Figure 7. Proposed process for production of $\alpha$-LA-enriched whey protein concentrate using membrane separation technology. $\mathrm{MF}=$ microfiltration; PVDF = polyvinylidene fluoride; VR = volume reduction. 
Table 3. Estimation of manufacturing costs for $\alpha$-LA-enriched whey protein concentrate with $80 \%$ protein (WPC 80 )

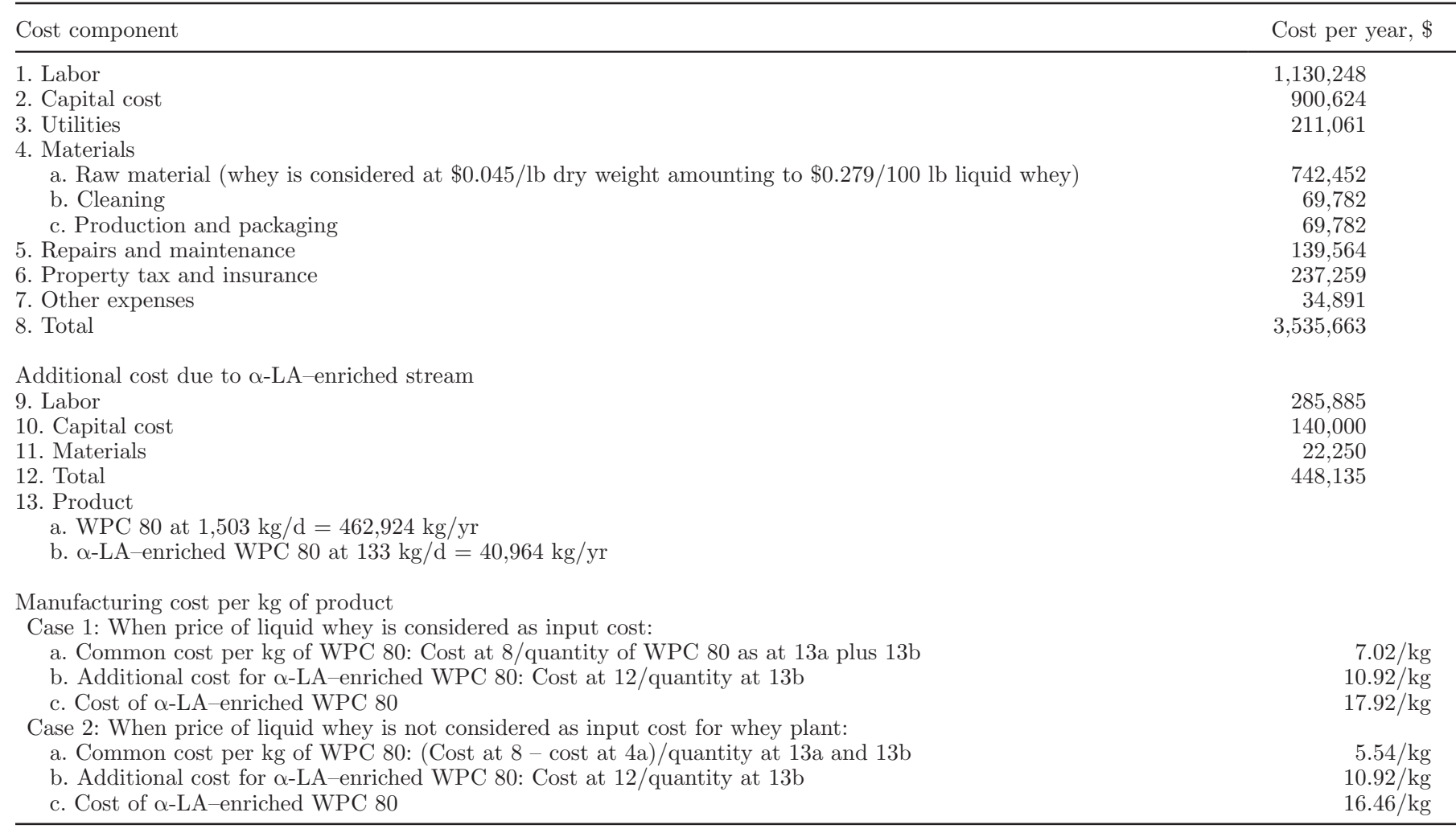

the permeate stream using a PES $5 \mathrm{kDa}$ membrane produces an $\alpha$-LA-enriched WPC that can be dried to obtain $\alpha$-LA-enriched WPC 80 powder.

\section{ACKNOWLEDGMENTS}

We gratefully acknowledge the financial support provided by Dairy Management Inc. (Rosemont, IL) as administered by Dairy Research Institute (Chicago, IL), and Agricultural Experiment Station, South Dakota State University (Brookings) for carrying out this project. We also acknowledge the supply of GMP standard by Davisco Foods International Inc. (Le Sueur, MN).

\section{REFERENCES}

Alomirah, H. F., and I. Alli. 2004. Separation and characterization of $\beta$ lactoglobulin and $\alpha$ lactalbumin from whey and whey protein preparations. Int. Dairy J. 14:411-419.

AOAC. 2005. Official Methods of Analysis. Vol I. 18th ed. Association of Official Analytical Chemists, Gaithersburg, MD.

Attia, H., M. Bennasar, and J. Taroda dela Fuente. 1991. Study of the fouling of inorganic membranes by acidified milks using scanning electron microscopy and electrophoresis. I. Membrane with pore diameter of $0.2 \mu \mathrm{m}$. J. Dairy Res. 58:39-50.

Ayers, J. S., D. F. Elgar, K. P. Palmano, M. Pritchard, and G. B. Bhaskar. 2006. Process for separation of whey proteins using a novel anion exchanger. Massey University and New Zealand Dairy Board, assignee. US Patent No. 7,018,665.
Bentham, A. C., M. J. Ireton, M. Hoare, and P. Dunnill. 1988. Protein precipitate recovery using microporous membranes. Biotechnol. Bioeng. 31:984-994.

Bottomley, R. C. 1991. Process for obtaining concentrates having a high $\alpha$-lactalbumin content from whey. Express Food Groups Ltd., assignee. US Patent No. 5,008,376.

Bramaud, C., P. Aimar, and G. Daufin. 1995. Themal isoelectric precipitation of $\alpha$-lactalbumin from a whey protein concentrate: Influence of protein-calcium complexation. Biotechnol. Bioeng. 47:121-130

Bramaud, C., P. Aimar, and G. Daufin. 1997. Whey protein fractionation: Isolectric precipitation of $\alpha$-LActalbumin under gentle heat treatment. Biotechnol. Bioeng. 56:391-397.

Casal, E., A. Montilla, F. J. Moreno, A. Olano, and N. Lorzo. 2006 Use of chitosan for selective removal of $\beta$ Lactoglobulin from cheese whey. J. Dairy Sci. 89:1384-1389.

Chatterton, D. E. W., G. Smithers, P. Roupas, and A. Brodkorb. 2006. Bioactivity of $\beta$-LG and $\alpha$-LA- technological implications for processing. Int. Dairy J. 16:1229-1240.

Couriol, C., S. Le Quellec, L. Guihard, D. Molle, B. Chaufer, and Y. Prigent. 2000. Separation of acid whey proteins on the preparative scale by hyperdiffusive anion exchange chromatography. Chromatographia 52:456-472.

Ganjam, L. S., W. H. Jr. Thornton, R. T. Marshall, and R. S. Mac Donold. 1997. Antiproliferative effect of yoghurt fractions obtained by membrane dialysis on cultured mammalian intestinal cells. J. Dairy Sci. 80:2325-2329.

Gésan-Guiziou, G., G. Daufin, M. Timmer, D. Allersma, and C. van Der Horst. 1999. Process steps for the preparation of purified fractions of $\alpha$-lactalbumin and $\beta$-lactoglobulin from whey protein concentrates. J. Dairy Res. 66:225-236.

Heebøll-Nielsen, A., S. F. Justesen, and O. R. Thomas. 2004. Fractionation of whey protein with high capacity superparamagnetic ino exchangers. J. Biotechnol. 113:247-262. 
Hurst, S., R. D. Alpin, and D. M. Barbano. 1990. Whey powder and whey protein concentrate production technology, costs and profitability. Part 4 of a research effort on cheddar cheese manufacturing, A.E.Res. 87-3, Dept. Agric. Res. Managerial Econ. Cornell University, Ithaca, NY

Kiesner, C., I. C. Radecker, H. Meisel, and W. Buchheim. 2000. Manufacture of $\alpha$-lactalbumin enriched whey system by selective thermal treatment in combination with membrane processes. Lait 80:99-111.

Kuo, K., and M. Cheryan. 1993. Ultrafiltration of acid whey in a spiral wound unit: Effect of operating parameters on membrane fouling. J. Food Sci. 48:1113-1118.

Lee, D. N., and R. L. Merson. 1976. Prefiltration of cottage cheese whey to reduce fouling of ultrafiltration membranes. J. Food Sci. 41:403-410.

Lucas, D., M. Rabiller-Baudry, L. Millesime, B. Chaufer, and G. Daufin. 1998. Extraction of $\alpha$-lactalbumin from whey protein concentrate with modified inorganic membranes. J. Membr. Sci. $148: 1-12$.

Markus, C. R., B. Olivier, G. E. M. Panhuysen, J. Van der Gugten, M. S. Alles, A. Tuiten, H. G. M. Westenberg, D. Fekkes, H. F. Koppeschaar, and E. E. H. F. de Haan. 2000. The bovine protein $\alpha$ lactalbumin increases the plasma ratio of tryptophan to the other large neutral amino acids and in vulnerable subjects raises brain serotonin activity, reduces cortisol concentration and improves mood under stress. Am. J. Clin. Nutr. 71:1536-1544.

Mehra, R., and P. M. Kelley. 2004. Whey protein fractionation using cascade membrane filtration. Bull No. 389. Int. Dairy Federation, Brussels, Belgium.

Merin, U., and M. Cheryan. 1980. Factors affecting the mechanism of flux decline during ultrafiltration of cottage cheese whey. J. Food Proc. Preserv. 4:183-198.

Morr, C. V., and E. Y. W. Ha. 1993. Whey protein concentrates and isolates: Properties and functional properties. Crit. Rev. Food Sci. Nutr. 33:431-476.

Muller, A., B. Chaufer, U. Merin, and G. Daufin. 2003a. Prepurification of $\alpha$ lactalbumin with ultrafiltration ceramic membranes from acid casein whey: Study of operating conditions. Lait 83:111129.
Muller, A., B. Chaufer, U. Merin, and G. Daufin. 2003b. Purification of $\alpha$ lactalbumin from a prepurified acid whey: Ultrafiltration or precipitation. Lait 83:439-451.

Papadatos, A., M. Neocleous, A. M. Berger, and D. M. Barbano. 2003. Economic feasibility evaluation of microfiltration of milk prior to cheesemaking. J. Dairy Sci. 86:1564-1577.

Pearce, R. J. 1995. Enriched whey protein fractions and methods for the production thereof. Commonwealth Scientific and Industrial Research Organization, assignee. US Patent No. 5,455,331.

Peters, R. H. 2005. Economic aspects of cheese making as influenced by whey processing options. Int. Dairy J. 15:537-545.

Roger, L. R., J. L. Maubois, L. B. Guibourg, G. Brule, and M. Piot. 1984. Process for obtaining an $\alpha$ Lactalbumin enriched product from whey and uses thereof. Institut National de la Recherche Agronomique, assignee. US Patent No. 4,485,040.

Svanborg, C., H. Agerstam, A. Aronson, R. Bjerkvig, C. Duringer, W. Fischer, L. Custafsson, O. Hallgern, I. Leijonhuvud, S. Linse, A. Mossberg, H. Nilsson, J. Petterson, and M. Svensson. 2003. HAMLET kills tumor cells by an apoptosis-like mechanism-Cellular, molecular and therapeutic aspects. Adv. Cancer Res. 88:1-29.

Taddei, C., P. Aimar, G. Daufin, and V. Sanchez. 1988. Factors affecting fouling of an inorganic membrane during sweet whey ultrafiltration. Lait 68:157-176.

Tomasula, P. M., and N. Parris. 1999. Whey protein fractionation using high pressure or supercritical carbon dioxide. United States of America as represented by the Secretary of Agriculture, assignee. US Patent No. 5,925,737.

Turhan, K. N., and M. R. Etzel. 2004. Whey protein isolate and $\alpha$-lactalbumin recovery from lactic acid whey using cation exchange chromatography. J. Food Sci. 69:66-70.

Uchida, Y., M. Schimatani, T. Mitsuhashi, and M. Koutake. 1996 Process for preparing a fraction of $\alpha$-lactalbumin from whey and nutritional compositions containing such fractions. Snow Brand Milk Products Inc., assignee. US Patent No 5,503,864.

Yang, F. Jr., M. Zhang, J. Chen, and Y. Liang. 2006. Structural changes of $\alpha$-lactalbumin induced by low $\mathrm{pH}$ and oleic acid. Biochim. Biophys. Acta 1764:1389-1396. 